Imagining the Past

Visitor specific applications for Al Zubarah Archaeological Site, Qatar

Kinzel, Moritz; Tanaka, Mina

Publication date:

2015

Document version

Publisher's PDF, also known as Version of record

Citation for published version (APA):

Kinzel, M., \& Tanaka, M. (2015). Imagining the Past: Visitor specific applications for Al Zubarah Archaeological Site, Qatar. 


\section{Imagining the Past}

\section{Visitor specific applications for Al Zubarah Archaeological Site, Qatar}

\author{
Moritz Kinzel \\ Dept. of Cross-Cultural and Regional Studies - ToRS \\ University of Copenhagen \\ Copenhagen, Denmark \\ zdr147@hum.ku.dk
}

\author{
Mina Tanaka \\ Interactive Media \& Space Consulting \\ Communication \& Information Operations \\ Dai Nippon Printing Co., LTD.(DNP)Tokyo, Japan \\ tanaka-m5@mail.dnp.co.jp
}

\begin{abstract}
Since the inscription of Al Zubarah Archaeological Site on the UNESCO World Heritage List, the number of visitors has almost tripled. To ensure the protection and preservation of the fragile remains, visitors have only limited access to the site. Therefore it is important to enhance the visitor experience and to support the dissemination of results of the ongoing excavations. Besides traditional techniques, the Qatar Islamic Archaeology and Heritage Project in cooperation with DNP have developed two mobile applications with AR-elements and interactive components to engage especially young visitors to explore the site and to reflect upon the past.
\end{abstract}

Index Terms: Al Zubarah, Site presentation, mobile application, AR, education.

\section{INTRODUCTION}

Al Zubarah Archaeological Site was listed as an UNESCO world heritage in June 2013 as one of the best preserved late 18 s century cities of the Gulf region [1]. In contrast to the general recognition of "organic grown", Arabic respectively Islamic towns Al Zubarah shows a well-organized grid system and town planning. All important elements [20] are present: e.g. a town wall with 23 towers and a number of gateways, mosques -five are identified so far, walled palatial compounds, and residential courtyard houses, as well as market and production areas.

Al Zubarah town was founded around 1765 at the northwest coast of Qatar and is nowadays part of Al Zubarah Archaeological Site which also includes the ruined settlement of Qal'at Murair and the modern Al Zubarah Fort. The town was destroyed in 1811 by troops send by the Sultan of Oman and did not recover since then. It seems that only temporary dwelling were erected occasionally in the years after. Around 1845 to 1885 , it was resettled on $1 / 6$ of the earlier town area reusing mainly the stone and plaster material from the earlier houses. But the later, town did not reflect the ridged grid system of the earlier phase. After the final abonnement of the settlement, the ruins were only occasionally visited by the local Bedouin tribes, but not resettled as such [8], [19].

The Qatar Islamic Archaeology and Heritage project (QIAH) was initiated in 2008 as a cooperation between Qatar Museums and the University of Copenhagen. The fieldwork carried out by QIAH started in 2009. It is a holistic project taking all issues of archaeology and heritage (management) into consideration. Site presentation, conservation and archaeological research are going hand in hand and are interlinked to reach a common understanding [2], [7], [8], [9], [10]; [12], [13], [14], [15], [16], [17], [18], [19].

\section{EXCAVATIONS AND SITE PRESENTATION}

The conservation strategy for Al Zubarah Archaeological Site foresees that there should be only limited access to the site to protect the fragile vestiges [7],[8],[9]. By defining clear marked visitor and service (vehicle) tracks, used by the archaeologists, craftsmen and other service staff have minimized the human impact on site considerable. Only parts and areas of great interest should be accessible and connected with a walking track. QIAH has developed so far two visitor tracks in the southern and central part of the site. Track One was opened in 2012 and is equipped with a series of more traditional hard copy info panels, regularly updated according to new archaeological finds and research results. The track runs through the southern part of the town and follows in general the historic street grid. After passing the town wall the visitor is lead into the urban quarters. Half way to historic harbor zone the track turns southwards to pass by one of the socalled fortified compounds (QMA4), excavated in the early 1980s and restored recently by QIAH. Opposite of the excavation area are the remains of one of the five mosques identified so far at $\mathrm{Al} \mathrm{Zubarah}$. The track is heading then to the large palatial compound (ZUEP04). A series of AR-elements are accessible here. The palatial compound is under excavation since 2010 , measures approx. $110 \times 100 \mathrm{~m}$, and compromises nine main courtyards [2]. Around the courtyards room sequences are arranged including smaller secondary courtyards with adjunct rooms. Until now, major excavation works have taken place in precinct 7 and 8 . In precinct 7 , a series of monumental arches and depictions of water vessels were uncovered. The findings are indicating various functions in the different parts of the courtyard compounds and a clear hierarchy of the excavated spaces. The elaborated plaster decorations around the arches show the wealth of the influential merchant families and the importance of $\mathrm{Al} \mathrm{Zubarah}$ for the $18^{\text {th }}$ century trade in the Gulf region.

\section{APPLICATION BACKGROUND}

In December 2013, Al Zubarah Fort, built in 1938, was restored and re-opened as the visitor center for Al Zubarah 
Archaeological Site [4], [18]. The Fort houses since an introduction to the history and archaeology of Northwest Qatar and $\mathrm{Al}$ Zubarah. It also presents some information on Zubarah's trade connections, archaeological finds and environment. Due to the harsh climate conditions technical equipment was kept there to a minimum.

To enhance the visitor's experience in addition to printed dissemination material, two mobile applications were developed: 1) a tour guide for adults and 2) a tour guide for children; both are available in English and Arabic. For the future more languages are in preparation. In the first place, the applications were developed for apple devices only (to be used on a set of devices available at the visitor center). The adult version is available for iPhone and iPad; the children's version is only available for iPad because it is more user-friendly for children. However, recently a redevelopment for Androidsystems has been initiated.

The tour guide for adults is designed especially for tourists to use at the archaeological site. It uses AR technology to show the past images comparing with the current landscape of the site and enriches their understanding. The second version of the tour guide app is designed as an educational tool for the children to learn more about the archaeological site and its archaeology. It also uses AR technology to provide enjoyment to children on site. The applications are an integral part of the low impact site management strategy at $\mathrm{Al}$ Zubarah Archaeological Site. The application has to be seen as an additional offer to access the presented information. Still the main issue with mobile applications on-site under the environmental conditions in Qatar is that most screens have not enough contrast to compete with the intense sun light. Optional shades or low-reflection films for the devices can reduce the impact considerably, but not completely. The fast development process of mobile devices and their operational systems makes it not always possible to adjust complex app content to all available systems and to upgrade to newer once.

\section{APPLICATION CONCEPT AND USE}

The concept for the adult version of the app is based on a traditional tour guide structure (Fig.1). If the visitors approach guidance points, mobile devices beep and let them know by coordinating with GPS. Therefore they would not miss the guidance points in the extensive archaeological site. Via a map and guidance points, information can be accessed (Fig.2). The app provides additional information which is not already present on the information panels. Additional images also make the excavation process and finds stored away visible to the visitors. AR technology enables to show the 3D images of palatial compound which existed before (Fig. $3 \& 5$ ), as well as enable the viewers to compare pre and post excavation scenes of the archaeological site. Each AR marker is provided with the information panel at the guidance point on site (Fig.3). They are not provided from the web site because this application also functions as invitation to lead the people to Al Zubarah. The visitors can see the past images which can't be seen anymore through this APP and understand what existed in the past and how the excavation work have done.
On the other hand, children's version is created as if children can enjoy treasure hunting. Making the most of AR technology, they find the markers one by one on site and capture them with a camera of tablet. Then the content starts. Markers are not provided from the web because the application is intended to be used on site especially during field trip of Qatari schools and young tourists accompanied by their parents. One of the contents reproduces the former architecture of $\mathrm{Al}$ Zubarah which cannot be seen now on the spot (Fig. 4 and 5). And also it enables the viewers to enjoy games and jigsaw puzzles based on the results from the excavation and the archaeological work processes in general (Fig. 6, 7 and 8). Children can enjoy a visit to the site and learn about it whilst also acquainting themselves with the most up-to-date archaeological research techniques. They merely have to pass their app-installed iPad over anyone of the six original markers in place at the ruins to start game and quizzes to learn about excavation and archaeological site. In addition, it can reproduce $\mathrm{CG}$ images of the erstwhile buildings as they once would have appeared at the marker point to enjoy easy-tounderstand and enlightening CG images, photographs and footage of what life was like in bygone days. The use of markers forces the user actually to visit the points of interest on site to access the full content of the app.
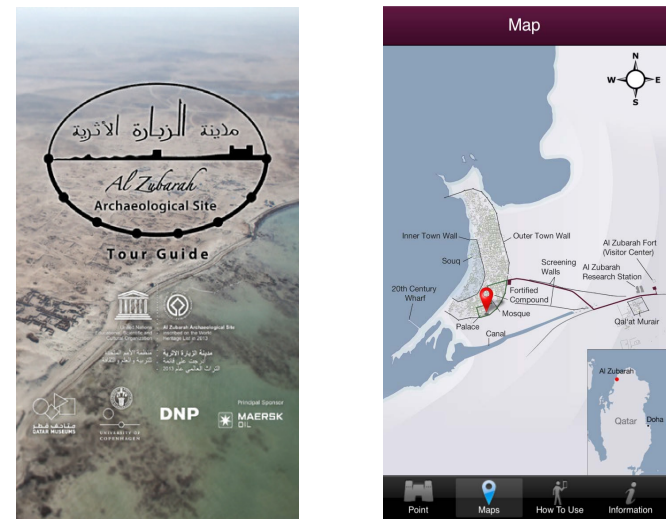

Fig. 1. APP Front page

Fig. 2. Map with guidance points

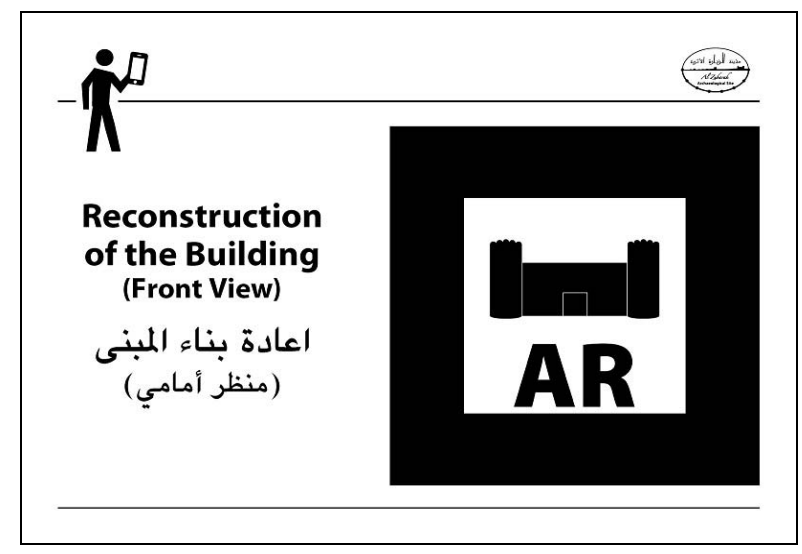

Fig. 3. Information panel with AR marker for adult version iPhone APP Reconstruction of the Building, AR(Front View) 
So, while many difficulties are being faced in the reproduction of buildings through construction and the preservation of artifacts at time of excavation at the site, this app manages to combine consideration of preservation needed at a World Heritage Site together with the need to open the site to the public.

At the moment the app explains points of interest along visitor track 1, including the palatial compound, but will be sequentially expanded in step with the progress of excavation work and opening of additional visitor tracks. The images included provide a much deeper insight into the working processes and show various excavation stages and work processes step by step. Especially the "Learn more"-section integrated in the children's version offers a variety of materials as well as audio tracks. The information for the young visitor is built into a series of quests aiming to let them move to learn spontaneously. After a quest/task is successfully completed the users can see the "Learn more"-section and after they have visited all pages of a section, a tool is added to their archaeological tool box. Each time a quest is completed they are promoted and they receive a new title name, such as "assistant", "novice archaeologist", etc. After having completed all quests, they can finally call themselves "archaeologist" to encourage them to visit all points of interest and continue exploring the site.

\section{CONCLUSION}

There is a great potential for mobile applications on archaeological sites to visualize archaeological findings and research results, especially with AR-elements. Making historical contexts visible right on the spot will enhance the visitor experience and the understanding of the past. At Al Zubarah Archaeological Site the first steps are taken and the content of the application will be extended according to the development of the site and the excavation process. A balanced use of different technologies helps to disseminate the research results widely and to support the protection and preservation of the actual archaeological remains.

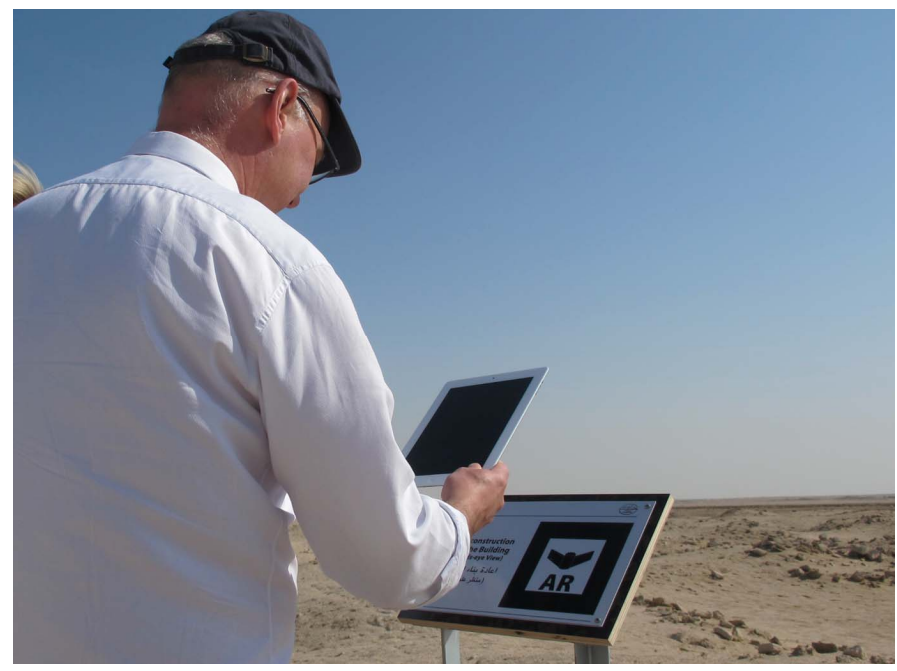

Fig. 4. AR tests on site.

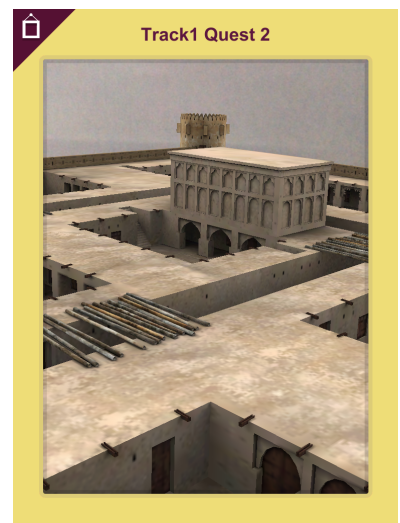

Fig. 5. Reproduction of palatial compound (ZUEP04) with AR-element.

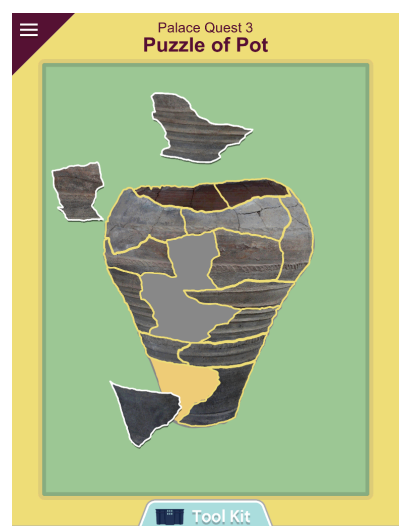

Fig. 6. Quest 3: Puzzle section of children's APP

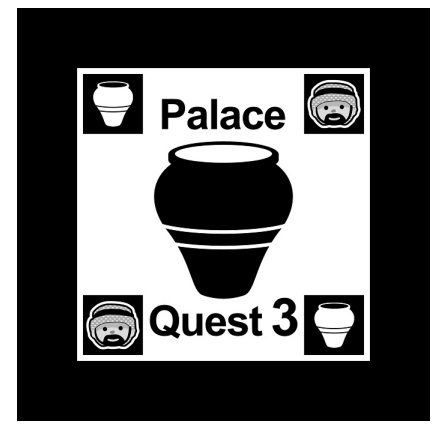

Fig 7. Marker for Quest 3.

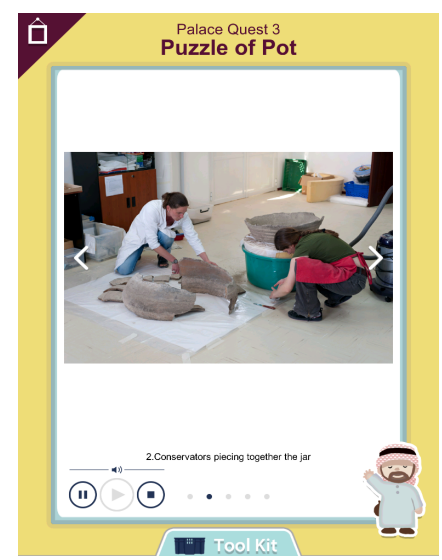

Fig. 8. Learn more section of children's APP with audio. 


\section{FOOTNOTES}

For the general (adult) guidance application for AZAS:

https://itunes.apple.com/us/app/al-zubaraharchaeological $/$ id937666257? $\mathrm{mt}=8$

For the kid's version: https://itunes.apple.com/us/app/abu-dibstour-guide-al-zubarah/id953344778? $\mathrm{mt}=8$

Official UNESCO WH page on Al Zubarah Archaeological Site: http://whc.unesco.org/en/list/1402

QIAH project page at the University of Copenhagen: http://miri.ku.dk/projekts/qiahp/zubarah/

QM-homepage with reference to Al Zubarah Archaeological Site: http://www.qm.org.qa/en/project/al-zubarah

DNP [Dai Nippon Printing Co., Ltd]

http://www.dnp.co.jp/eng

\section{ACKNOWLEDGMENT}

The development of the applications was generously supported by McerskOil Qatar as the principal sponsor of Al Zubarah Archaeological Site. The QIAH project work at Al Zubarah would have not be possible without the generous support by Qatar Museums and Her Excellency Sheikha Al Mayassa Bint Hamad Bin Khalifa Al Thani, Chairperson of QM; as well as His Excellency Sheikh Hassan Bin Mohammad Bin Ali Al Thani, Vice-Chairperson of QM; Mr. Faisal alNaimi, Head of Archaeology; Mr. Adel al-Moslamani, Head of Restoration; Dr. Ingolf Thuesen, Executive Director of QIAH.

All images and screenshots are by QIAH/QM \& DNP.

\section{REFERENCES}

[1] http://whc.unesco.org/en/list/1402 [accessed 08.05.2015].

[2] Collie, T. 2012. Al Zubarah Excavation Point 4 (ZUEP04). In: Richter, T. (ed.) 2012. Qatar Islamic Archaeology and Heritage Project: Archaeology Section, End of Season Report. Stage 2, Season 2. 2010-2011. University of Copenhagen and Qatar Museums Authority. p. 39-55.

[3] de Cardi, B. 1978. Gazetteer of Sites and Finds. In B. de Cardi (ed.): Qatar Archaeological Report: Excavations 1973. University Oxford Press: Oxford. 180-201.

[4] Fuchs, C. 2014. Al Zubarah Fort (ZUEP12). In: Rosendahl, S. (ed.): Qatar Islamic Archaeology and Heritage Project, 2014 End of Season Report. University of Copenhagen and Qatar Museums Authority; p. 69-77.

[5] al-Kholafi, M. J. 1987. Zubara \& Merwab Monuments, report 1983 \& 1984 / Mohammad Jassim Al-Khulaifi. Doha: Ministry of Information, Department of Tourism \& Antiquities, 1987.

[6] al-Kholafi, M. J. 2006. The Traditional Architecture in Qatar; (2nd edition); Doha: National Council for Culture, Arts and Heritage.
[7] Kinzel, M. 2013. Conservation Handbook for Al Zubarah Archaeological Site. Doha/Copenhagen: University of Copenhagen - ToRS.

[8] Kinzel M. 2014 Al Zubarah - eine vergessene Legende. Ausgrabung, Erhaltung, Präsentation. In: Koldewey Gesellschaft (Ed.): Bericht über Die 47. Tagung für Ausgrabungswissenschaft und Bauforschung. Trier 2012.2014 Dresden: Thelem Universitätsverlag.

[9] Kinzel M., Sobott R., and Thuesen I. 2012 Conserving Zubarah. Towards A Conservation Strategy for Al Zubarah Archaeological Site / Qatar. In: Proceedings of the Seminar of Arabian Studies 43 -2013; Oxford: Archaeopress, 167 - 176.

[10] McPhillips, S. (ed.) 2012. Qatar Islamic Archaeology and Heritage Project: Archaeology Section, End of Season Report. Stage 2, Season 3. 2011-2012. University of Copenhagen and Qatar Museums Authority.

[11] Niebuhr, C. 1774 (1997). Reisebeschreibung nach Arabien und anderen umliegenden Ländern. Mit einem Vorwort von Stig Rasmussen und einem biographischen Portrait von Barthold Georg Niebuhr. Zürich: Manesse Verlag.

[12] Parry, J. (2013). The Pearl Emporium of Al Zubarah. https://www.saudiaramcoworld.com/issue/201306/.htm [accessed 16.07.2015]

[13] Richter, T. (ed.) 2011. Qatar Islamic Archaeology and Heritage Project: Archaeology Section, End of Season Report. Stage 2, Season 1. 2009-2010. University of Copenhagen and Qatar Museums Authority.

[14] Richter, T. (ed.) 2012. Qatar Islamic Archaeology and Heritage Project: Archaeology Section, End of Season Report. Stage 2, Season 2. 2010-2011. University of Copenhagen and Qatar Museums Authority.

[15] Richter T., Wordsworth P. \& Walmsley A. 2011. Pearl fishers, townsfolk, bedouin, and shaykhs: economic and social relations in Islamic al-Zubārah. In: Proceedings of the Seminar for Arabian Studies 41 (2011): 1-16. Oxford: Archaeopress.

[16] Richter, T., al-Naimi, F.A., Yeomans, L., House, M., Collie, T., Jensen, P.B., Rosendahl, S., Wordsworth, P., and Walmsley, A. 2012. The 2010-2011 excavation season at al-Zubarah, northwest Qatar (poster). In: Proceedings of the Seminar for Arabian Studies 41 (2011): 331-340. Oxford: Archaeopress.

[17] Rosendahl, S., Nymann, H., Kinzel, M., \& Walmsley, A. (Eds.) 2013. Qatar Islamic Archaeology and Heritage Project: End of Season Report: Spring 2013. Copenhagen: University of Copenhagen and Qatar Museums Authority.

[18] Rosendahl, S. (ed.) 2014. Qatar Islamic Archaeology and Heritage Project, 2014 End of Season Report. University of Copenhagen and Qatar Museums Authority.

[19] Walmsley, A. 2011. The Legacy of Zubarah. In: Qultura, December 2011: 58-65.

[20] Wirth, E. 2000. Die Orientalische Stadt. Mainz: Phillip von Zabern. 